\title{
УДК:7.5046 821.161.1
}

ББК: 85.103

DOI: $10.18688 /$ aa2111-07-57

M.N. Tsvetaeva

\section{The Prophet and the Thinker: The Quest for Paradise in the Pictorial and Religious Philosophy of A.A. Ivanov}

In the thematic range of A. A. Ivanov's (1806-1858) work, a special place belongs to Biblical and Evangelical scenes devoted to "the miraculous" and images "heavenly world" revealed in pictorial and figurative language of secular art.

A significant body of articles (Gogol [19]; Khomyakov [9]; Filosofov [7]; Kozhevnikov [11]; Zummer [23]; Alpatov [4]; Berstein [5; 6]; Rakova [13]; Zagyanskaya [22]; Allenov [2; 3]; Stepanova [14; 15]; Kopirovsky [10]) has been dedicated to the work of A. A. Ivanov, an outstanding Russian historical thinker, prophet, and philosopher. He truly was a world-renowned artist who brilliantly mastered the language of antiquity, classical academism, as well as romantic tendencies and opened a new page in portrait and landscape painting. The artist sought to combine the achievements of Russian culture (its psychologism, the desire for the sacred, the cult of deep nature) with the great traditions of world culture; specifically, Egyptian and Christian art, the work of the great masters of the Renaissance - Giotto, Leonardo da Vinci, Ghirlandaio, Raphael, Titian, and Veronese. He studied the paintings of the Tombs of the New Kingdom, the book by the German thinker I. G. Herder 'On the spirit of Jewish Poetry', the work of the German scientist Strauss 'The Life of Jesus', and 'The History of the Jewish War' by Josephus. He was influenced by Gogol and N. M. Rozhalin, by the circle of 'Lyubomudrov' and the romantic philosophy of Schelling, by the tendencies associated with the names of A.I.Herzen, N.P. Ogarev, and I.M. Sechenov. In historical subjects, he managed to express the spirit of the time, reflect the spiritual, philosophical, and moral experiences of the Russian intelligentsia, its dreams and ideals, which may not had met Christ. His dialogue with the ideological searches of Overbeck and the Nazarenes, the concept of the universe by Tyutchev, the lectures of Tirsch, the ideas of Venevitinov, Shevyrev, Kireevsky, and Odoyevsky is striking.

But, a special role in his work belongs to the stories from the Bible and Gospels. It should be noted that, although the Russian intelligentsia (writers, artists, poets, musicians) was hungry for Christ, the secular art of the $19^{\text {th }}$ century was unable to penetrate the hidden, mystical, liturgical, and soteriological meaning of the Savior's sufferings, reaching only to His psychological and earthly torments: the Cross, Crucifixion, and Calvary. The mysteries of His divine nature, the mystery of His soul-saving sacrifice, His voluntary martyrdom, and Resurrection have not been revealed to secular art. Of the divine power of the Son of Man, the Apostle John the Theologian says: "And when He said to them,' This is I, 'they drew back and fell to the ground" (John 18: 6). In secular art, there was dissociation from the creativity based on prayerful and ascetic work, and then the sensual and bodily worldview prevailed. 
Many artists after A. Ivanov, such as N. N. Ge, I. N. Kramskoy, I. E. Repin, M. M. Antokolsky, V.D. Polenov, V. M. Vasnetsov, M. V. Nesterov, M. A. Vrubel, turned to Christian philosophy, the preaching of Christ, and His Word. However, the image of the Savior was perceived through the prism of the earthly, sensual, personal, and the lack faith. Basically, the artists gave Christ only "their philosophy", their spiritual ideas, feelings and thoughts, "intelligences" that differ from spiritual ones, emphasizing certain facets and qualities of His personality. Sometimes Christ was seen as a sufferer, betrayed and deceived, then as an earthly prophet, orator, populist, revolutionary, and the defender of the humiliated and oppressed (Kramskoy), then as a great poet, dreamer, lyrical contemplator of beauty, and wanderer (Polenov), then as an innocent victim, tormented and fervently suffering, destroyed by human malice and hatred (Ge and Vrubel).

To understand Alexander Ivanov's special path, it is necessary to first understand the reasons that allowed him to make a turn towards the spiritual and temporal, as well as his the appeal to Byzantine and ancient Russian art, not so much in form, but in the prayerful ascetic feat, which opened up new ways for the development of art in the $19^{\text {th }}-20^{\text {th }}$ centuries.

To understand the ontological, spiritual, and artistic transition, it is important to refer to the testimonies of Nikolay Gogol who managed to reveal the secret of his work, "the path to finding faith, the works and torments that could turn into inner spiritual work" [19, p. 146]. Indicating that his works were also connected in a wonderful way with the soul and inner education, Gogol pointed out that, by the will of Providence, the work on the picture had turned into the education of the artist, both in the "hand-made artwork" and in the thoughts that guide art to a higher purpose. Gogol wonders where the artist could have found a model to depict the main task of the whole picture - "to represent the whole course of human conversion to Christ... Where could he have gotten it from? Out of his head? Created with his imagination? Comprehended in thought process? No, it is nothing! The thought is cold for this, and the imagination is insignificant. Ivanov strained his imagination, ... tried to catch the high movements of the soul on the faces of all the people he met, stayed in churches to follow the prayer of a person and saw that everything was powerless and insufficient ... And this was the subject of great suffering of his soul and the reason that the picture was so long delayed. No, until a true conversion to Christ has taken place in the artist himself, it is impossible for him to depict Him on the canvas. Ivanov prayed to God for such a complete conversion, shed tears in silence, asking Him for the strength to fulfill the idea He had inspired.... Ivanov asked God to incinerate his grace, which in the cold callousness afflicted many of the best and kindest people, and inspire him to depict such a conversion in the manner that could touch the soul even of a non-Christian looking at his painting" [19, pp.145-146]. In this context, how can we not recall the path and work of A.S.Pushkin and his famous "Prophet"?

For our time, the problem of the spiritualization of art through inspiration of the artist's soul is relevant. Gogol, whose portrait was introduced by A. Ivanov into his canvas, speaks of insufficiency of only technical skills,

"There are people who are sure that everything is available to a great artist. The land, sea, person, frog, fight, people playing cards, and a prayer to God, - everything is easy if only he is a talented artist and studied at the Academy. The artist can only depict what he felt...otherwise the picture would be a dead, academic picture..." [19, p. 144] 
Analyzing the psychology of the multi-figure composition (the images of John the Baptist, future apostles, Pharisees, the free and the slaves), Gogol notes that the artist managed to capture this "wonderful light" on the faces of the chosen ones, while others are still trying to get into the meaning of the words - "Behold the Lamb, take away the sins of the world", and still others say, "From Nazareth the prophet does not come". And He, in the heavenly calm and wonderful distance, is already approaching people with a quiet and firm foot [19, p. 144].

Speaking about the impoverishment of faith, Gogol claims that a real artist who has taken up religious creativity usually goes against the opinions of the epoch, shouting to him, "What is the connection between the soul and the picture? The soul is in itself, and the picture is in itself. We should wait for your appeal! You must be a Christian without that; after all, we are all here true Christians" [19, p. 146].

Turning to the analysis of the pictorial and figurative system of Ivanov in such works as 'The Archangel Gabriel strikes Zacharias dumb' (1850), 'The Annunciation to the Virgin Mary', 'The Dream of Joseph', and 'Walking on the Waters', it is necessary to note the role of ancient Russian painting and its great followers. In biblical and gospel sketches, he used the effect of luminescence, fluctuation, and vibration of the form in order to achieve weightlessness and dematerialization of the classical form, its sculptural three-dimensionality, gravity, weight, and volume.

The sketches of the wall painting "The Resurrection of Christ" intended for the Church of Christ-the-Saviour built by K. A. Ton were made by 1845, in which A. A. Ivanov makes contact with Byzantine mosaic, the language of Old Russian iconography. Peering into the creation of monumental painting, he creatively studies the "colors of joy", color modes, "the wisdom of color combinations", the color silhouette, which is the driving force that reduces the dynamics of individual surfaces, then intensely reveals its color potency. Color silhouettes of different tension create the effect of the space getting closer and then further away - the effect of the breath of the icon plane, its mysterious life.

As V.N. Shchepkin notes, the symbolism of icon painting, its colors and lines, in contrast to the symbols of modernity, were always "healthy and clear symbols", because an icon painter of the Rublev era always remained in the "sphere of religious feelings and sought sensations not for their own sake and not because of "vague" (and often unhealthy) searches in this or other life. If the Russian icon painter had certain "sensualism in his attitude to the paint and the line, it was the sensualism completely different from the modern one: innocent, soft, and simple-minded... What was earthly in it was enlightened by entering into religion, but it did not lose its delicate shade" [21, p.59]. The symbols corresponded to ideal representations, such as the "elegant crescent shape" of St. Andrey Rublev, which cannot be found in either Euclidean or higher geometry. The color and space of the icon has an "insubstantial" appearance, endowed with the "divine light".

Remarkably, Byzantine painters were equated with the most revered saints, because a master in the process of "painting an image is in a state of mystical unity with God" [20, p. 78]. Analyzing the pictorial and figurative language of Byzantium, particularly the painting of Nikolai Mesarit, Y.A. Pyatnitsky in his article "The Artistic language of the Byzantine icon" notes that there are two levels of knowledge in religious painting: phenomenal (pictorial) and noumenal (semantic), the meaning of which is to transfer the viewer to the world of superbeing, to perceive the "ultimate reality" [20, p. 78]. Byzantine colorology is such that by means of successive 
illuminations and shading, the artist created the impression that color is woven not from material threads and paint, but from light and shadow, a light-bearing and life-giving source of Divine energies. The experience of understanding light, its dynamics, dramaturgy, and influence on the classical form was acquired by A. Ivanov in many sketches devoted to ancient images, for example, 'Venus de Medicea' (1830-31).

In the theory of ancient Russian art, spiritual and psychic energies - the light and the color - characterize the worlds that emit them. Denoting religious and existential representations and figurative symbolism, the categories of light and color reveal the ontological, soteriological, symbolic, moral, anagogic, psychological, and liturgical plans of a work of art. In his sketches of the 1850s, such as 'The Last Supper', 'Christ and Nicodemus', 'Flagellation of Christ', 'Women who knew Christ and look at the crucifixion from a distance', Ivanov immerses the viewer in the atmosphere of the "brown" background space, opening the perceptual horizons of painting. The symbolism and semantics of the brown color combining black and red denotes the image of blood and death, the psychology of the events preceding the passion cycle, Calvary, and the torments of Christ. At the same time, Ivanov opens up the way to the understanding of color in the Russian avant-garde. Being the phenomena of the deepest spirituality, the pictorial and spatial constructions of Ivanov are not a fiction or a game of the mind, but the deepest creative insight into the Gospel events, the embodiment of their spirit and psychology. The connections of color and music, the desire for musical beauty of lines and plastic perfection of form, harmony, and "ensemble" of action connect Ivanov with representatives of new forms in art, such as V. Kandinsky.

The transfer of atmosphere of the event and continuation of the image of the "brown" that we find in Kandinsky's work was a sign of the spiritual situation in Russia preceding the revolution. Developing the aesthetic of color in the spiritual dimension, revealed in the legacy of the great masters of the past, in the neo-Romanticism of the Silver Age, Kandinsky says, "The brown hung in the air". In his book "On the Spiritual in Art" [11], he strongly rejects any manifestation of irrationality in the creative process that is not supported by spiritual content. Speaking vigorously against his constructivist opponents, he declares that abstract means of expression do not yet mean depth of content, that there are dead triangles (whether they are white or green), as well as dead chickens, dead horses, dead guitars. It is as easy to become a "realistic academician" as it is to become an "abstract academician". His main idea is that a form without content is not a hand, but an "empty glove". Describing the physical and psychosomatic effects of colors, reflecting on the symbolism of color, Kandinsky spoke of "fragrant colors" that cause spiritual vibrations like a flame, like red color. Discovering the possibilities of the synthetic art and theory of synesthesia, combining color and music, Kandinsky likened the sky blue color to the sound of a flute, and the dark blue to a cello, deepening in tune with a double bass. The combination of red and black-brown easily "extinguishes the flame" and too easily can arise "blunt, rigid, incapable of movement" [8, p.46]. Like many others, he was drawn to the biblical origins and types. In 1911, reflecting on pure energies, on pointlessness and "no-imagery", he wrote about the perception of life through the eyes of a "young-old man", about children's play and fantasy as the basis of art.

Relying on personal religious experience, in his gospel-based paintings, Ivanov reveals the secrets of being, the beauty of the universe through the transmission of the infinite, picturesque 
energies, the rhythm and music of space in their pro- and counter-sound. With the help of color-spatial solutions, the artist sought to overcome the earth gravity. His work was related to the ancient Russian heritage, the psychologism of icon painting, the desire to portray a Divine miracle. "After all, what we call earthly life or just life has always struck or strikes with the fatal absence of someone in it, constant separation from someone. All artistic creativity, for example, follows from the fact of this separation, since it seeks to bring into our world what has fallen out of it. And the true image is not the one that gives us a resemblance to any part of the world, but the one that enters the world (whether it is the starry sky or someone's soul) as an addition to a harmonious whole" [21, p. 68].

Many Russian avant-garde painters absorbed the prophetic spirit of Russian art, with its thirst for height and depth, eternal and heavenly. However, the tragic break with traditions and history - with spiritual and prayerful work and the appeal to non-Christian mysticism, theosophy, gave rise to temptations.

Another feature that attracted Ivanov is "angelicness", the theme of "purity of heart" (sketches of 1830-40, 'Two women's heads', 'Two heads in a turn'). It is found in the images of John the Theologian and the 'Angel and Zacharias. "Angelicness" becomes a characteristic feature in the appearance of a man, the inner depth and height, which is the image and likeness of God. In the same way, "angelic" in their meekness, quietness, childish wisdom, purity, humble grace, and sacrificial love, the apostles Peter and Paul were depicted by the genius of Rublev, who maximally expressed the visible image of both Christian and national virtues, combining them in a harmonious series. G. S. Dunaev saw "angelic" in the "ideal” female images by F. S. Rokotov, V.L. Borovikovsky, Alexander Ivanov, in the 'Petrograd Madonna' by K. S. Petrov-Vodkin, to make sure that "Rublev's angels are not accidental, but as if the quintessence of all Russian painting, and maybe culture, its intonation..." [21, p. 121].

Seeing the meaning of art and the purpose of an artist in depicting life in all its manifestations, Leo Tolstoy noted that every great artist should create her own forms. In his painting 'The Appearance of Christ to the People' (1837-1857), Alexander Ivanov depicted the traditional "wandering" subjects of world culture in a new way: the dialogue of contrasting characters coming from antiquity (for example, the crying Heraclitus and laughing Democritus), the motives of processions, meetings, farewells, recognitions, transformations, and the typology of anticipation developed by ancient Russian painting.

Analyzing the historical theme of Ivanov, who was brought up on the classical tradition, we see his conscious departure from the everyday element. The comparison of the specific features of genre painting with the phenomena of Russian culture, such as vaudeville, literature, and journalism, helps to identify the features of morphology and syntax of "genre" heroes, caricature, poetic, dramatic, and reflect the formula type, particularly social, religious, and philosophical contents. In his sketches, there has been a movement towards the discovery of the internal layering of the nation. In his historical painting, he analyzed its conciliarity and disunity, the abundance of intonations, mental and figurative experiences, developing a plot through a large number of drawings, studies, and poetic sketches of the nude. It is noteworthy that they opened the way to the socio-dramatic paintings of I. E. Repin and V. I. Surikov. His historical genre included portraits and single-figure compositions, everyday sketches and movement to open air landscape painting of the Silver Age; the series 'Boys among the landscape' were picked up by 
the masters of Russian and European art such as Matisse and Petrov-Vodkin. Like a composer, he developed solo acts and duets, trios and ensembles, where each document of human life represented an undeniable value by high criteria of spiritual and moral tasks of art $[16 ; 17 ; 18]$.

In order to understand the high structure of biblical intonations, spiritual movements, and their differences from everyday life, Ivanov also studied the style of the "conversational genre". In his multi-figure genre compositions, he demonstrated the subtle humor of the story, the brightness of gestures and voices, conveying the elusive richness of nature, the dynamics of "unnecessary grace and grandeur” - 'Ave Maria' (1839), 'October Holiday Sighing Dance' (1842), 'October Holiday At the Ponte Molle' (1842), 'The Israelites dance before the Golden Calf' (1850s).

While advocating for the "pure idea", the divine beauty, and harmony in art, Ivanov wanted the next generations of Russian artists to make a path to the "high road to the glory of Russia". In this case, instead of the 'Miracle of Bolcena' and 'Attila, winning the blessing of the Pope', the descendants would see "brilliant eras from world and Russian history filled with all the antiquarian precision, much needed in the present age" [1, p. 106].

In its ontological essence, the historical genre in literature and art tends to parables, allegory, religious and epic mysteries, metaphorical images, and biblical meanings. In his prophetic and philosophical work, Ivanov studied the themes of faith, doubts about humanity, and its moral and spiritual foundations, which form the semantic basis of his painting 'The Appearance of Christ to the People', and which ceases to belong only to his time. Reflecting on the eternal, he poses a question to everyone, "What response does the Good Message Baptist, his sermon, evoke? How do the free and the slave, the poor and the rich, the old and the new react to it?" Ivanov does not give a spiritual answer psychologically dissecting reality. According to the Gospel, only John the Baptist, who was given a sign from above, could see Christ. He saw "the heavens opening, and the Spirit like a dove descending upon Him. And the voice was from heaven: You are My Beloved Son, in Whom I am well pleased" (Mark 1: 10-11). As an artist with a prophetic mindset and master of psychological analysis, he puts the question to the point: is humanity, ancient or modern, capable of meeting Christ according to its inner constitution, according to the voice of conscience, faith, hope, and the experience of its sorrows; or will it pass by like the Pharisees, Sadducees, and scribes - the Russian intelligentsia?

Ivanov's method, based on a perfect mastery of classical form and color, far surpassed the three-color description of the world adopted in classicism, opening the movement to impressionism, the masters of the Blue Rose. Filled with spiritual and philosophical reflections on the high mission of an artist - to correct and heal the mores, Alexander Ivanov has himself become an actor and questioner, depicting himself along with Gogol in his painting.

Thus, the historical work of Ivanov, his biblical and Evangelical cycles went far beyond his time. It elevated the viewer to the high moral and religious sense of art, gave deeper reflection on the values of life, and caused the searching for pictorial and figurative tools to reach new artistic and ideological horizon - movement to the heavenly, the quest for the visual concept of the "spiritual" in the Russian and world art. 


\section{References}

1. Alexander Andreevich Ivanov. Ego zhizn' i perepiska (His Life and Correspondence) 1806-1858. St. Petersburg, 1880. 477 p. (in Russian).

2. Allenov M. M. Alexandr Ivanov. Moscow, Izobrazitel'noe iskisstvo Publ., 1980. 208 p. (in Russian).

3. Allenov M. M. Alexander Andreevich Ivanov. Leningrad, Khudozhnik RSFSR Publ., 1989. 32 p. (in Russian).

4. Alpatov M. V. Alexandr Andreevich Ivanov: Zhizn' i tvorchestvo (Alexandr Andreevich Ivanov: Life and Work), vol. 1-2. Moscow, Iskusstvo Publ., 1956, pp. 107-114 (in Russian).

5. Bernstein B.K. On the Question of the Formation of the Aesthetic Views of Alexander Ivanov. Iskusstvo (Art), 1957, no. 2, pp. 39-43 (in Russian).

6. Bernstein B. Alexander Ivanov and Slavophilism. Iskusstvo (Art), 1959, no. 3, pp. 58-66 (in Russian).

7. Filosofov D. V. Ivanov and Vasnetsov in the Assessment of Alexander Benois. Mir iskusstva (Art World), 1901, no. 10, pp. 217-233 (in Russian).

8. Kandinsky V. O dukhovnom v iskusstve (Zhivopis')(On the Spiritual in Art (Painting)). Leningrad, Leningradskaia galereia Publ.,1989. 68 p. (in Russian).

9. Khomyakov A.S. Ivanov's Painting: A Letter to the Editor. Russkaia beseda (Russian Conversation). 1858, book 1, pp. 1-22 (in Russian).

10. Kopirovsky A.M. System of Monumental Mural Paintings by Alexander Ivanov ('Biblical Sketches') Theology within Religion Studies. Review of the Christian Academy for the Humanities, 2014, vol. 15, iss. 2, pp. 65-73 (in Russian).

11. Kozhevnikov V. A. Znachenie A. A. Ivanova v religioznoi zhivopisi (The Meaning of A. A. Ivanov in Religious Painting). Moscow, 1907. 4 p. (in Russian).

12. Mashkovtsev N. The Creative Path of Alexander Ivanov. Apollon (Apollo), 1916, no. 6-7, pp. 1-39 (in Russian).

13. Rakova M. A. A. Ivanov. Moscow, Iskusstvo Publ., 1960. 54 p. (in Russian).

14. Stepanova S. S. Russkaia zhivopis' epokhi Karla Briullova i Aleksandra Ivanova. Lichnost' i khudozhestvennyi protsess (Russian Painting of the Era of Karl Bryullov and Alexander Ivanov. Personality and the Artistic Process). St. Petersburg, Iskusstvo-SPb Publ., 2011. 287 p.

15. Stepanova S.S. Around a Masterpiece. The Appearance of Messiah of Alexander Ivanov: Farts and Myths, "Secrets" and Scientific Problems. Mal'tseva S. V.; Stanyukovich-Denisova E. Yu.; Zakharova A. V. (eds.). Actual Problems of Theory and History of Art: Collection of Articles, vol. 8. St. Petersburg, St. Petersburg State University Publ., 2018, pp.254-266. Available at: http://dx.doi.org/10.18688/aa188-3-24 (accessed 1 May 2020) (in Russian).

16. Tsvetaeva M. N. Khristianskii vzgliad na russkoe iskusstvo: ot ikony do avangarda (Christian View of Russian Art: From the Icon to the Avant-Garde). St. Petersburg, Christian Academy for the Humanities Publ., 2012. 304 p. (in Russian).

17. Tsvetaeva M.N. "Sacrament of the Soul" in the Russian Portrait of the $18^{\text {th }}$ Century. Matica Srpska Journal of Fine Arts, 2019, no. 47, pp.93-101 (in Russian).

18. Tsvetaeva M.N. Ecology of Culture: Nature, Human Civilization in the Artistic and Information Space of the Russian World. Studia Slavica et Balcanica Petropolitana, 2019, no. 2 (26), pp. 240-243 (in Russian).

19. Vinogradov I. A.; Voropaev V.A. (comp.). Gogol N. V. Dukhovnaia proza (Gogol N. V. Spiritual Prose). Moscow, Otchii Dom Publ., 2001. 568 p. (in Russian).

20. Vizantiia skvoz' veka (Byzantium through the Centuries), Exhibition Catalogue. St. Petersburg, The State Hermitage Museum Publ., 2017. 428 p. (in Russian).

21. Vzdornov G. (ed.). Troitsa Andreiia Rubleva. Antologia (Trinity of Andrey Rublev. Anthology). Moscow, Iskusstvo Publ., 1981. 216 p. (in Russian).

22. Zagyanskaya G. A. Peizazhy Aleksandra Ivanova. Problema zhivopisnogo metoda khudozhnika (Landscapes of Alexander Ivanov. The Problem of the Artist's Pictorial Method). Moscow, Iskusstvo Publ., 1976. 119 p. (in Russian).

23. Zummer V.M. The System of Biblical Compositions by A. A. Ivanov; Analysis of 13 Complex Story Cycles with comp. by prof. G. G. Pavlutsky "Sources of Artistic Creativity of A. A. Ivanov". Kiev, S. V. Kulzhenko Publ., 1915. 34 p. (in Russian). 
Title. The Prophet and the Thinker: The Quest for Paradise in the Pictorial and Religious Philosophy of A. A. Ivanov

Author. Tsvetaeva, Marina Nikolaevna - Ph. D. (art history), full doctor (cultural studies), professor. St. Petersburg State Institute of Film and Television. Ul. Pravdy, 13, 191119 St. Petersburg, Russian Federation. mtsvetaeva@rambler.ru ORCID:0000-0001-7826-4039

Abstract. The article is devoted to the biblical and evangelical theme in the works of A. A. Ivanov - an outstanding thinker of the historical genre, a painter-philosopher and prophet, who influenced the development of Russian and European art of the $19^{\text {th }}-20^{\text {th }}$ centuries; in particular, on Ge, Vrubel, Surikov, Nesterov, and Kandinsky. The testimonies of Nikolay Gogol, who notes the significance of the personal finding of Christ by Ivanov, is an important document for understanding his spiritual and aesthetic concept, the plots devoted to the image of the "miraculous" and the formation of a new pictorial and figurative language in such works as 'The Archangel Gabriel strikes Zacharias dumb' (1850), 'The Annunciation to the Virgin Mary', 'The Dream of Joseph', 'Walking on the Waters'. Hence, his turn to comprehend Byzantine and Old Russian culture while working on sketches for the wall painting of the Church of the Resurrection of Christ in 1845 is quite natural. In the biblical and evangelical sketches, he used the effects of glowing, luminescence techniques, achieving the dematerialization of the classical form, its sculptureness, three-dimensionality, and volume. Thus, Ivanov's historical works on the biblical and evangelical cycles went far beyond the limits of their time, lifting the viewer to the high order of moral and religious meaning of art, to deep reflection on the values of being, allowing them to enter a new artistic and ideological language.

Keywords: angelness, Byzantine art, heavenly world, Gogol, iconography, Kandinsky, psychology of image, prophecy, philosophy of color, Christian worldview, miraculous

Название статьи. Пророк и мыслитель: поиски «горнего» в живописно-религиозной философии А. А. Иванова

Сведения об авторе. Цветаева Марина Николаевна — доктор культурологии, кандидат искусствоведения, профессор. Санкт-Петербургский государственный институт кино и телевидения, ул. Правды, 13, Санкт-Петербург, Российская Федерация, 191119. mtsvetaeva@rambler.ru ORCID:0000-0001-7826-4039

Аннотация. В данной статье речь идёт о библейско-евангельских сюжетах А.А.Иванова - выдающегося мыслителя исторического жанра, живописца-философа и пророка, повлиявшего на пути развития русского и мирового искусства XIX-XX вв., на творчество Ге, Врубеля, Сурикова, Нестерова, Кандинского. Важным документом для понимания его духовно-эстетической концепции, сюжетов, посвящённых изображению «чудесного» и формированию нового живописно-пластического языка в таких произведениях, как «Архангел Гавриил поражает Захарию немотой» (1850), «Благовещение Деве Марии», «Сон Иосифа», «Хождение по водам» являются свидетельства Н. В. Гоголя, который отмечает значимость личного обретения Христа А. Ивановым. Органичным является его поворот к осмыслению византийской и древнерусской культуры при работе над эскизами к стенописи храма Воскресения Христова в 1845 г. В библейско-евангельских эскизах он использовал эффекты свечения, приёмы люминесценции, достигая дематериализации классической формы, её скульптурности, трёхмерности и объёма. Таким образом, исторические работы и библейско-евангельские циклы А. Иванова далеко выходили за рамки своего времени, вознося зрителя к высокому строю и нравственно-религиозному смыслу искусства, к глубинному размышлению о ценностях бытия, позволяющих выйти на новый художественно-мировоззренческий язык - движение к горнему.

Ключевые слова: ангеличность, византийское искусство, горний мир, Гоголь, иконопись, Кандинский, психология образа, пророчество, философия цвета, христианское мировоззрение, чудесное 